\title{
Legal Policies for Implementing Online Waqf in Indonesia
}

\author{
RR. Dewi Anggraeni, ${ }^{1}$ Nur Rohim Yunus, ${ }^{2}$ Annissa Rezki ${ }^{3}$ \\ Universitas Pamulang Banten, Universitas Islam Negeri Syarif Hidayatullah Jakarta, \\ Universitas Jayabaya, Jakarta. \\ https://doi.org/10.32507/mizan.v4i1.599
}

\begin{abstract}
The development of technology can not merely facilitate long-distance communication, more than that it can facilitate in all matters such as administrative and transaction management. In previous years ago, everything was done manually but currently as technology advances, all work is carried out through online system. Consequently, today the online system is not only applied in the field of transportation and communication, but also has also joined into health, education and worship agencies such as ZISWAF activities (Zakat, Infaq, Shadaqah, and Waqf). With this online system, everything becomes easier and accessable. No more queueing or having to drive back and forth, but all have done effectively and efficiently. This study aimed to find out how waqf are carried out through online system by applying qualitative descriptive method, while the literature study techniques is utilized a normative approach. The focus of the discussion is related on how to implement online waqf, in addition to the implementation of its law, also how to ensure that the administrative process has been carried out correctly and appropriately without any doubt about the elements of deception in it.

Keywords: Online Waqf, Online Transactions, Policy
\end{abstract}

\begin{abstract}
Abstrak
Perkembangan teknologi tidak hanya dapat memfasilitasi komunikasi jarak jauh, lebih dari itu dapat memfasilitasi dalam segala hal seperti administrasi dan manajemen transaksi. Dahulu kala, semua dilakukan secara manual namun saat ini seiring kemajuan teknologi, semua pekerjaan dilakukan melalui sistem online. Alhasil, saat ini sistem online tidak hanya diterapkan di bidang transportasi dan komunikasi, tetapi juga telah tergabung dalam lembaga kesehatan, pendidikan dan ibadah seperti kegiatan ZISWAF (Zakat, Infaq, Shadaqah, dan Waqf). Dengan sistem online ini, segalanya menjadi lebih mudah dan dapat diakses. Tidak perlu lagi antri atau harus mondar mandir, tapi semua sudah dilakukan dengan efektif dan efisien. Penelitian ini bertujuan untuk mengetahui bagaimana wakaf dilaksanakan melalui sistem online dengan menerapkan metode deskriptif kualitatif, sedangkan teknik studi pustaka menggunakan pendekatan normatif. Fokus pembahasan terkait bagaimana cara pelaksanaan wakaf online, selain pelaksanaan hukumnya, juga bagaimana memastikan bahwa proses administrasi telah dilakukan dengan benar dan tepat tanpa ada keraguan mengenai unsur-unsur penipuan di dalamnya.
\end{abstract}

Kata Kunci: Wakaf Online, Transaksi Online, Kebijakan

* Naskah diterima tanggal: 13 Januari 2020, direvisi: 15 Februari 2020, disetujui untuk terbit: 2 Maret 2020.

${ }^{1}$ RR. Dewi Anggraeni is a Senior Lecturer at Pamulang University, Banten. E-mail: dewifhunpam@yahoo.com.

${ }^{2}$ Nur Rohim Yunus is a Senior Lecturer at Universitas Islam Negeri Syarif Hidayatullah Jakarta. E-mail: nurrohimyunus@uinjkt.ac.id.

3 Annissa Rezki is a researcher at Jayabaya University. E-mail: annissa_rezki@yahoo.com 


\section{A. INTRODUCTION}

The development of technology is making a human life easier. Especially when it comes to general financial matters where every transaction requires transparency. Etymologically, waqf comes from Arabic language which is derived from the word waqafa means to hold, stop, stay still, or stand. The word waqafa-yaqifu-waqfan means the word habasa-yahbisu-tahbisan meaning that it is forbidden to use. The word waqf in Arabic contains the meaning of at-tahbis or at-tasbil, which means to hold, or to hold the represented property, not to be transferred. ${ }^{4}$

According to Shaykh Syihabuddin al-Qalyubi, endowment (waqf) is holding property that can be taken advantage of by preserving the original form to be distributed to the allowed way. ${ }^{5}$ As for the term, waqf according to Abu Hanifah is to hold property under the auspices of the owner accompanied by the provision of benefits as shadaqah (habs al-'aini 'ala milk al-waqif wa tasadduq bi al-manfa'ah). ${ }^{6}$ Besides, in the law number 41 of 2004 concerning waqf, it is defined as legal acts of the wakif (a giver of endowment) to separate and/or surrender a portion of his property to be used forever or for a certain period for worship and/or public welfare which suitable to the sharia compliance. ${ }^{7}$

To conclude, waqf can also be interpreted as a noble practice by handing over some of the durable owned assets to be used by many people and intended to reach the blessing of Allah SWT. The main sources of law in Islamic law are the Qur'an and AsSunnah or Al-Hadith.

In the discussion above, several questions arise as the focus of research, namely how is the legal policy on waqf implementation in Indonesia? How does the practice of waqf and its development coincide with technological advances in the current modern era?

\section{B. METHODS}

This legal study applied a descriptive qualitative approach specifically by using a literature and empirical approach. This study is intended to explain, systematize, analyze, interpret, and assess positive legal norms concerning the implementation of online waqf in Indonesia. The primary data used are in the form of a law on waqf, while the secondary data is taken in the form of a literature review which includes literature on the practice of online waqf in Indonesia. The collected data is then analyzed using qualitative descriptive methods.

${ }^{4}$ Muhammad ibn Bakar ibn Mandzur al-Mishri, Lisan al-'Arab, (Bulaq: Al-Mishriyah, 1301 H), Jilid 11, p. 276; Wahbah Zuhaili, Al-Figh al-Islamy wa 'Adillatuhu, (Mesir: Dar al-Fikri, 1985), 7599

${ }^{5}$ Muhammad Abid Abdullah al-Kabisi, Hukum Wakaf terj. Ahrul Sani Faturrahman dkk, (Jakarta: DD Republika dan IIMan, 2004), p. 113; Abu Zahrah, Muhadharat fi al-Waqf, (Beirut: Dar al-Fikr al-'Arabi, 1971), 41

${ }^{6}$ Alauddin Muhammad bin Ali Al-Hafsaki, al-Dur alMukhtar, t.h. t.p. vol.iv, p.532.

${ }^{7} \mathrm{~A}$ law number 41 of 2004 concerning waqf or endowment 


\section{RESULTS AND DISCUSSION}

\section{Online Waqf Practices in its Validity}

Online Waqf is one of the ways or transactions carried out with an online (computerized) system offered by ZISWAF institutions for people who want to give their waqf fund. The purpose of this online waqf is to invite all parties wherever they are, to get involved and care for others. Among the assets of twelve (12) waqf that can be collected through online waqf are assets in the form of money or cash-waqf and waqf through money.

The management of waqf began to be noticed by the government with a marking on the existence of a regulation namely Government Regulation Number 28 of 1977 concerning the waqf fund of Land Ownership, however this regulation is limitedly regulating waqf activities only in the form of land. It shows that the practice is remained the same with the waqf model in the early period, which was identically to the landbased waqf, and its use is also limited to religious social activities, such as mosques, cemeteries, Islamic boarding school, and others. Furthermore, along with the existence of the Religious Courts established under Law Number 7 of 1989 concerning Religious Courts, a guideline for resolving disputes regarding waqf experienced by Religious Court judges is still lacking if only based on the provisions of Government Regulation Number 28 of 1977. For this reason, Presidential Instruction Number 1 of 1991 concerning the Compilation of Islamic Law was established. ${ }^{8}$

The issuance of Law Number 41 of 2004 became an initial point for the waqf management practice in Indonesia. Waqf property can be used more productively since it contains understanding and management patterns of empowering more modern waqf potential. By regulating waqf in the form of a law, the waqf can become an alternative solution to improve the socio-economic welfare of the community. ${ }^{9}$ Consequently, one of the developed sources of waqf is in the form of the cash-waqf.

Online Waqf is using an indirect contract, which does not require any meeting between waqif and nadhir to hand over the represented-assets, but the contract is remained conducted according to the procedures agreed upon by the waqif by utilizing an online system. Implementation of an online waqf agreement is easy, simply by completing the form provided by the online waqf institution, while money can also be transferred through online mechanism.

Firstly, the Waqif sent money through accounts that have been chosen by themselves and made a transfer's receipt as a prove for the waqif. After the waqf fund received by an online waqf account, then the waqf institution will send an acceptance of waqf fund to the waqif, and finally waqif is able to check the information on the official website.

${ }^{8}$ Ministry of Religion of the Republic of Indonesia. The Guide of Strategic-Productive Land-based Waqf. Directorate General of Islamic Community Guidance Directorate for Waqf Empowerment in 201, p. 29-30

'Darwanto, "Wakaf Sebagai Alternatif Pendanaan Penguatan Ekonomi Masyarakat Indonesia", Jurnal Ilmu Manajemen Dan Akuntansi Terapan, Vol 3 Nomor 1, Mei 2012, hlm. 6. 
Law Number 41 of 2004 Article 18 mentioned that: "In some condition whenever Waqif can not declare the waqf pledge verbally or can not be present in the implementation of the waqf pledge for reasons justified by law, then the waqif can appoint his power of attorney statement strengthened by 2 (two) witness." 10

The contract used in the online waqf conducted by waqif on the Sinergi Foundation is applying an indirect contract (aqad), where a waqif indirectly hands over his assets to nadhir that managed an online system, it is conducted by the waqif through filling out the forms provided by the online-waqf institution. Because, when a waqif filling out the provided form then it means that he has indirectly agreed to everything that has been determined by the online institution.

Moreover, the existence of 2 (two) witnesses in waqf is also playing important role, since waqf is categorized as tabarru' worship, since worship does not require any witnesses, but everything related to the law is required to be proven with authentic evidence, because in the modern era everything has cause and effect side. Without intending being arrogant (riya') for his action but to optimize intentions and for the implementation of waqf itself.

After making a waqf agreement, between a waqif and nadhir in addition to the presence of 2 witnesses. In article 17 letter a it is mentioned that "waqf pledge is carried out by the waqif to nadhir in the presence of the Acting Board for Endowment Pledge (PPAIW) witnessed by 2 (two) person." The KHI article 218 stated that waqf can be carried out if only witnessed by at least 2 person, but the implementation of online waqf there are required no witnesses at all, because waqif do not meet in one assembly with Nadir, therefore, the online waqf mechanism do not provide witnesses when handing over waqf.

An agreement made by an online waqf institution is not carried out directly, but by filling out the form provided by an online waqf means that indirictedly waqif has already agreed upon a contract. Meanwhile, the disadvantage of this system is since there are no two witnesses required in the online waqf, consequently, when the problems arise in the implementation of online waqf then it cannot be accounted before the state.

\section{Provisions in Waqf}

Waqf is a form of worship activity that is highly recommended for Muslims, because the reward of waqf will always received although the waqif has died. This notion is proven by the statement of Rasulullah SAW in a popular hadith narrated by Ahmad bin Hanbal from Abu Hurairah: "When a person dies, then all his deeds will be cut except for three cases: almsgiving Jariyah (including waqf), the knowledge that is used, and pious children who pray for him."11

${ }^{10}$ Ministry of Religion of the Republic of Indonesia, Association of Legislation Regarding Waqf, p.

${ }^{11}$ Hadits no 9079, Kitab al-Musnad, chapter Musnad Abu Hurairah. 
In the implementation of a waqf, it is necessary to understand concerning the pillars of waqf. In classical books, such as Raudah at-Talibin, it is stated that the pillars of waqf are four things, namely waqif (subject of waqf), mauquf (waqf object), mauqufalaih (waqf manager), and shigat (contract). ${ }^{12} \mathrm{Al}-\mathrm{Kh}$ atib in the book of al-Iqna' defines mauquf as a particular item that can be taken advantage of by not eliminating the item and is the property of the waqif. ${ }^{13}$

In the Qur'an, there are several verses that encourage muslims to give waqf. Some of them are QS. Ali 'Imran verse 92:

"Never will you attain the good (reward) until you spend (in the way of Allah) from that which you love. And whatever you spend - indeed, Allah is knowing of it." 14

The other verses that become a reference regarding waqf is Q.S Al-Baqarah verses 261 and 267:

"The example of those who spend their wealth in the way of Allah is like a seed (of grain) which grows seven spikes; in each spike is a hundred grains. And Allah multiplies (His reward) for whom He wills. And Allah is all-Encompassing and Knowing ".

"O who you have believed, spend from the good things which you have earned and from that which We have produced for you from the earth. And do not aim toward the defective therefrom, spending (from that) while you would not take it (yourself) except with closed eyes. And know that Allah is Free of need and Praiseworthy.".

In addition to the Al-Qur'an as the main reference in practicing waqf, there is also a hadith that is used as the basis for practicing waqf. Such as the hadith from Abu Hurairah R.A which stated that Rasulullah SAW said: "When a human die, his deeds are cut off, except for three cases: almsgiving, useful knowledge and pious children who pray for him" (HR. Muslim). ${ }^{15}$

\section{Distribution of Waqf}

Waqf can be divided into several classifications based on its purpose, time, and use: ${ }^{16}$

a. Waqf based on its purpose consists of:

1) Social Waqf for the good of the community (khairi), or if the waqf is aimed for the public interest.

${ }^{12}$ An-Nawawi, Raudah al-Talibin wa 'Umdah al-Muftin, t.p. t.h. II:252-256

${ }^{13}$ Muhammad al-Syarbini al-Khatib, al-Iqna' fi Hilli AlFadz Abi Syuja', t.p. t.h. II:73.

${ }^{14}$ This verse emphasizes the word of birr which means good-deeds and has a connection with the word of infaq. Therefore, this verse is often used as the main proposition of waqf which originates from the Al-Qur'an, namely 1) Good deeds, 2) Infaq, and 3) Possessions are the most beloved. Check Ali Amin Isfandiar, "Tinjauan Fiqh Muamalat dan Hukum Nasional tentang Wakaf di Indonesia", La_ Riba: Jurnal Ekonomi Islam, vol II, no. 1, (Juli 2008), p. 55.

${ }^{15}$ The Scholars redeemed shadaqah jariyah in the hadith above with the waqf. Jabir sid that none of the compansions of the Messenger of Allah had a deposit to hand over a waqf. See: Imam Taqiyuddin Abu Bakar bin Muhammad al-Husaini, Kifayat al-Akhyar, translated by. Syarifuddin Anwar (Surabaya: Bijna Iman, 2007), p. 720.

${ }^{16}$ Mundzir Qahaf, Manajemen Wakaf Produktif (Jakarta: Penerbit Khalifa, 2005), p. 161. 
2) Family Waqf (dzurri), defined as if the purpose of waqf is to provide benefits to waqif, his family and his descendants.

3) Combined Waqf (musytarak), i.e. if the waqf is intended both for the public and family together.

b. According to the time limit, waqf are divided into two types:

1) Eternal Waqf, namely waqf in the form of goods that are long-lasting such as land and buildings or movable property determined by waqif as eternal endowments.

2) Temporary Waqf, i.e. if the items represented are easily damaged when used without giving conditions for replacing damaged parts.

c. Based on its use, waqf are categorized into two types

1) Direct Waqf, or the endowments which principal goods are used to achieve its objectives such as mosques for prayer, schools for teaching and learning activities and so on.

2) Productive Waqf, or waqf which principal goods are utilized for production activities and the results are given in accordance with the objectives of endowments.

d. Pillars and Terms of Waqf. According to the scholars, there are four pillars of waqf or waqf elements, namely: ${ }^{17}$

1) Waqif (person who is giving a waqf). His condition must be independence, common sense, baligh (adults), not under the ability. Because waqif is the perfect owner of the property represented, then waqf can only be given if the land is perfectly owned by waqif.

2) Mauqufbih (goods or assets represented). The object must be considered valid by fulfilling the following conditions:

a) Waqf property has value (there is a price). The point is that in practice the property can be valued if it has been owned by someone, and can be utilized under any circumstances.

b) Waqf property is clearly in shape. It means that the object should be clearly known and noticeable, so it will not cause a dispute.

c) Waqf property is the property owned by waqif.

d) Waqf property in the form of objects that do not move, such as land, or objects that are adjusted to the existing waqf.

3) Mauquf 'alaih (purpose of waqf). Waqf must be utilized within the limits permitted by Islamic law, because it is a charity that aims to bring people closer to Allah. To avoid misuse of waqf, then waqif needs to confirm the purpose of waqf. Is the waqf object is represented to help his own family as

${ }^{17}$ Juhaya S. Praja, Perwakafan Di Indonesia (Bandung: Yayasan Piara, 1997), p. 27 
a family waqf, or for the poor ones, etc., or for the public interest which is clearly intended for good deeds.

4) Shighat (waqf pledge). The statement or pledge of waqf must be stated explicitly both verbally and in writing, with the editorial "I endow" or a sentence that is meaningful with it. But waqf shighat is enough with permission from the waqf and there is no need for a qabul from mauquf'alaih. This pledge is vital because it implies of the waqf ownership rights and property of waqf moved into being owned by Allah or public property which is used following with the waqf's own purpose.

\section{The Evidence of Online Waqf Transaction}

Online waqf institutions have mushroomed in Indonesia because of the enormous economic potential of Muslims in the form of cash-waqf. Previously, public seems to have not been fully aware of the appeared impact by cash-waqf if only all people did it. For this reason, these institutions are existed, not only as waqf distributors, but also as educators.

There are three types of waqf in the Muslim community, namely the waqf khaeri, waqf ahli, and waqf syuyu' $i$ which includes cash-waqf. The advantage of cash-waqf is its value will not diminish or even increase through safe investment. Its use is also more flexible than waqf in the form of immovable objects and other movable objects.

The waqf transactions can be carried out in two ways, namely; First, a waqif can directly come to the institution (offline) and/or confirm through online system, either by telephone or text format that has been determined by the institution. Hence, the online transaction-based is permitted in Islam, because there is a handover between waqif and nadzir.

The development of technology provides benefits for people who have full activities, only by a smartphone they can make waqf transaction in a short time without having to come to see Nazhir in person. ${ }^{18}$ However, it should be note that it is important for online transactions to consider the truth and authenticity of the documents. This practice is not only provided by the Indonesian Waqf Board (BWI), but recently the bank also provides online waqf services for all its customers.

The implementation of waqf online is easy to do, only by filling out the forms, however, the waqif have to look first at the programs offered by waqf institutions since there are many new and innovative waqf programs which aimed to increase people's knowledge about the development of online waqf in management.

The institution in managing waqf funds has many variations although some of the provider cannot be maximized in its management. With the programs owned by waqf online, it is expected that the community will be able to donate through waqf according

${ }^{18}$ Muslihatin, N. A. (2016). Analisis Hukum Islam Terhadap Wakaf Online (Studi Kasus di Sinergi 
to the expectation and under the appropriate law, so there will no problems arise in the future between waqf institution and waqif.

A Waqif is free to choose programs that have been provided by waqf institutions. Forms that have been provided are filled out by the waqif in accordance with existing provisions. The next step is to transfer money according to the program chosen, and the waqif shoul send a confirmation to the management, then they will go to the online institution to check the money that has been sent.

After the money is received, an online waqf institution provides information through their website. A waqif can check directly into the official website page. Waqf which carried out through online waqf institutions called individual waqif, whereas a waqif gives perfect assets without intermediaries, he hands over his asset by himself and its possessions to Nadir, in a legal way the waqif has fulfilled the individual waqif requirements.

Opinions of the scholars regarding waqif conditions, include: a) independence, b) common sense, c) adult (baligh), d) not under ability (wasteful / negligent). Waqif in conducting waqf has been fulfilled perfectly, because in the implementation of waqf using an online system, it means that waqif can already master the electronics properly can use the online system perfectly. In the online waqf, a waqif needs to the amount of money as a waqf fund. This has become a benchmark for waqif conditions who has perfectly met the requirements

Requirements for the validity of waqf assets, are: 1) The represented assets must be mutaqawwamit must be clearly stated where the waqif obtained his represented assets; 2) the assets to be represented by the waqif are known with certainty, the money represented is not the result of bad deeds, such as corruption. It would be better if the property represented is full property of waqif and binding for waqif when he gives as a waqf-asset. For this reason, it is prohibited to donate assets that do not belong to the waqif. Because waqf contained the possibility of vanishing property or donations therefore both can only be realized on objects that are owned.

The Article 16 of Law Number 41 Year 2004 explained that waqf property consists of: ${ }^{19}$ immovable objects and movable objects. Online Waqf uses movable objects, where waqif donates his wealth in the form of money. All items to be represented are valid only if it has fulfilled the conditions. The represented objects are visible and has clear boundaries, in the practice of online waqf, the visible form is represented in the form of money, if the money has reached the hands of Nadir and the limits have been agreed upon, before the waqif sends money to Nadir. The unclear waqf and which has no clear boundaries according to the ulema is not permitted. The form of online waqf is not visibly seen by eyes because the money is sent through an account, the money represented is not in front of Nadir directly. But as evidence in online waqf there is a receipt from the bank. The implementation of online waqf is indeed unclear, because nadhir cannot see the money directly in front of waqf. However, the contract is still valid.

\footnotetext{
19 The Indonesian Ministry of Religion, Association of Legislation Regarding Waqf, h.
} $17-18$. 
It is debatable matters among scholars regarding endowments that have eternal substance. Terms of endowment are there is no limit on the substance of the assets represented must be eternal. The waqf law already regulates it, there is a term waqf where a waqif can give a certain period before nadhir. The existing policy is fully carried out nadhir, the Hanafiyyah group requires that the wealth represented is 'ain (the substance) must be eternal which allows it to be utilized continuously.

Utilization of money represented by the waqif can be used continuously according to the purpose of waqf for people who can not afford and can be used in the long term. Online Waqf in the implementation of waqf gives full assets to an online waqf institution, in the form there are no rules about the time period, waqif gives his property fully. The purpose of waqf can work as it should and the assets represented can be taken advantage of, the wealth can be developed into greater.

\section{CONCLUSIONS}

Most of people still assume that the represented objects of waqf should be in the form of immovable objects, such as land or buildings for worship and so on. Therefore, waqf institutions are required to formulate strategies and fundraising models which help waqif to channel their waqf funds in addition to educate the public that waqf is not always imaged as asset-based. Cash-Waqf is one of the innovation forms in waqf practiced in Indonesia.

With the existence of cash-waqf, lands of waqf that have been neglected can be developed into a productive waqf project, which absolutely requires capital. As a result, the existence of cash-waqf and its development can be utilized as a means of producing land waqf that lacks capital for its management and development.

Interestingly, online Waqf is currently becoming one of the donation trends in Indonesia. It is noticeable because of the existence of many IT-based transactions. Before the waqf online existed, the public was more familiar with online shadaqah and online zakat. Many zakat institutions utilize ATM, android and website-based technology, to solicit public funds. Waqf which has a distinctive character also participates in the development of modern technology. Therefore, the existence of technology that develops massively can facilitate muamalah transactions of a waqif to give his waqf-asset.

\section{REFERENCES:}

Aji, A.M. Rasionalitas ijtihad Ibn Rusyd: kajian atas fiqh jinayat dalam kitab "Bidayat alMujtahid wa Nihayat al-Muqtashid, Bogor: Pustaka Pena Ilahi, 2010.

Al-Hafsaki, Alauddin Muhammad bin Ali. Al-Dur al-Mukhtar, t.h. t.p. vol. iv, h.532.

Al-Husaini, Imam Taqiyuddin Abu Bakar bin Muhammad. Kifayat al-Akhyar, terj. Syarifuddin Anwar (Surabaya: Bijna Iman, 2007), h. 720.

Al-Kabisi, Muhammad Abid Abdullah. Hukum Wakaf, diterjemahkan oleh Ahrul Sani Fathurrohman (et.al.), Jakarta: IIMaN Press, 2004, ix 
Al-Kabisi, Muhammad Abid Abdullah. Hukum Wakaf. terj. Ahrul Sani Faturrahman dkk, (Jakarta: DD Republika dan IIMan, 2004), h. 113;

Al-Khatib, Muhammad al-Syarbini. Al-Iqna' fi Hilli AlFadz Abi Syuja', t.p. t.h. II: 73.

Al-Mishri, Muhammad ibn Bakar ibn Mandzur. Lisan al-'Arab, (Bulaq: Al-Mishriyah, $1301 \mathrm{H})$, Jilid 11, h. 276;

Al-Munawar, Said Agil Husin. Hukum Islam dan Pluralitas Sosial, Cet 1, Jakarta: Pemadani, 2004, h. 138.

An-Nawawi, Raudah al-Talibin wa 'Umdah al-Muftin, t.p. t.h. II: 252-256.

Hadis nomor 9079, Kitab al-Musnad, bab Musnad Abu Hurairah.

Hanbal, Ahmad Ibn. Musnad Ahmad, t.p. Vol: xix h. 10.

Huda, Nurul. Manajemen Pengelolaan Tanah Wakaf di Majelis Wakaf dan Zakat, Infaq, Shadaqah (ZIS) Pimpinan Daerah Muhammadiyah Kabupaten Malang, (Malang: Skripsi FEUIN, 2009), h. 22.

Isfandiar, Ali Amin. "Tinjauan Figh Muamalat dan Hukum Nasional tentang Wakaf di Indonesia", La_ Riba: Jurnal Ekonomi Islam, vol II, no. 1, (Juli 2008), h. 55.

Kementerian Agama Republik Indonesia. Panduan Pemberdayaan Tanah Wakaf Produktif Strategis. Direktorat Jenderal Bimbingan Masyarakat Islam Direktorat Pemberdayaan Wakaf Tahun 2013, h. 29-30

Kementerian Agama RI, Himpunan Peraturan Perundangundangan Tentang Wakaf,...h. $17-18$.

Maggalatung, A.S.; Aji, A.M.; Yunus, N.R. How The Law Works, Jakarta: Jurisprudence Institute, 2014.

Muslihatin, N. A. Analisis Hukum Islam Terhadap Wakaf Online (Studi Kasus di Sinergi Foundation). (2016).

Praja, Juhaya S. Perwakafan Di Indonesia (Bandung: Yayasan Piara, 1997), h. 27

Qahaf, Mundzir. Manajemen Wakaf Produktif (Jakarta: Penerbit Khalifa, 2005), h. 161.

Undang-Undang Nomor 41 tahun 2004 tentang Waqaf

Zahrah, Abu. Muhadharat fi al-Waqf, (Beirut: Dar al-Fikr al-'Arabi, 1971), 41

Zuhaili, Wahbah. Al-Figh al-Islamy wa 'Adillatuhu, (Mesir: Dar al-Fikri, 1985), 7599. 